Agro-Science Journal of Tropical Agriculture, Food, Environment and Extension Volume 19 Number 1 (January 2020) pp. $1-10$

ISSN 1119-7455

\title{
EFFECT OF DIFFERENT PROCESSING METHODS ON CHEMICAL AND PASTING PROPERTIES OF TAMARIND (Tamarindus indica L.) SEED FLOURS
}

\author{
${ }^{* 1}$ Uzodinma E.O., ${ }^{1}$ Osagiede E.G. and ${ }^{2}$ Chikwendu J.N. \\ ${ }^{1}$ Department of Food Science \& Technology and ${ }^{2}$ Department of Human Nutrition \& Dietetics, \\ University of Nigeria, Nsukka, Enugu State, Nigeria \\ *Corresponding author's email: eunice.uzodinma@unn.edu.ng
}

\begin{abstract}
This study investigated the effect of autoclaving, boiling and roasting methods on the chemical and pasting properties of tamarind seed flour. The flours were analyzed for proximate composition, functional properties, selected mineral contents, anti-nutrients and pasting properties. Results indicated that there were significant $(p<0.05)$ differences in the moisture, protein, fat, fibre, ash and carbohydrate contents of the flour samples with values that ranged from 10.26-11.36, 19.64-24.23, 2.26-4.13, 3.25-4.55, 3.48-3.98 and 52.59-59.86\%, respectively. Significant $(p<0.05)$ differences were also observed in the values of selected functional properties and minerals (sodium, magnesium, potassium and phosphorus). Boiling method relatively reduced some of the anti-nutrients more effectively than others. Flour from boiled T. indica seeds could withstand heating and shear stress compared to other processed samples because of its low breakdown viscosity value. However, flour from roasted seeds had highest setback viscosity value among others and might withstand retrogradation better than others. Overall results indicated that autoclaved, boiled and roasted seed flours could be useful in pasta, noodle and bakery industries.
\end{abstract}

Key words: boiling, flour, pasting properties, tamarind seed flours, tamarind seeds, viscosity

\section{INTRODUCTION}

Tamarind is a highly wind-resistant tree which can be grown unattended in backyards, roadsides or wastelands and almost every part of the tree is useful (Singh et al., 2007). In inter-tropic zone, tamarind pulp, leaves and flowers are commonly consumed in various dishes and traditional drinks due to its high nutritive and calorific value. Tamarind tree bears pods containing about 10 brown seeds surrounded by an abundant acid pulp. Traditional processing for food preparation is widespread, whereas its commercial uses (pasteurized juices and tamarind paste) are still relatively unknown and under-developed (Singh et $a l .$, 2007). Tamarind seed as a by-product of the commercial utilization of the fruit has several uses. The seeds are rich in protein and can alleviate protein malnutrition widespread in many Asian and African countries. They are good sources of crude fibre, carbohydrate and mineral concentrations particularly potassium (Ajayi et al., 2006). The seeds also have the potential for substituting $30 \%$ of cereals in livestock rations (Singh et al., 2007). Presence of tannin, phytic acid, hydrogen cyanide, trypsin inhibitor and phyto-haemaglutinations in the seed testa, makes the whole seed unsuitable for consumption. The testa can produce some side effects such as depression, constipation and gastrointestinal disorder and must be removed by soaking or boiling in water and roasting (El-Siddig et al.,
2006). Moreover, the nutrient value of food can be changed by the way it is processed, cooked and stored. However, some food processing methods (soaking, boiling, roasting, blanching, autoclaving and fermentation) can enhance quality of processed foods through detoxification of anti-nutrients, flavour and colour development, among others (Oluseyi and Temitayo, 2015). Previous studies had reported the use of soaking, boiling, roasting, germination and fermentation to produce detoxified flours from tamarind nuts (El-Siddig et al., 2006; Oluseyi and Temitayo, 2015). However, information on the use of autoclaving in processing of tamarind seeds and pasting properties of processed flours from the seeds based on previous methods are limited. Hence, the aim of this study was to determine the effect of autoclaving, boiling and roasting methods on the chemical and pasting properties of flours produced from tamarind seeds.

\section{MATERIALS AND METHODS}

Tamarind seeds were purchased from Jasuwagwari Market, Minna in Niger State, Nigeria. Chemicals of analytical grade and equipment were obtained from Department of Food Science and Technology of the University of Nigeria, Nsukka and International Institute of Tropical Agriculture (IITA), Ibadan, both in Nigeria. 


\begin{abstract}
Processing Methods
Production of the different flours from the seeds Raw seeds of the tamarind fruits were manually sorted to remove stones and other contaminants and divided into five portions. The first portion was sun-dried during active sunshine hours ( 9 am $-5 \mathrm{pm}$ ) for four days to a constant moisture content of $8.0 \%$ at ambient conditions and milled without any form of processing (UTS). The second portion was also sun-dried for three days to constant moisture content of $8.5 \%$ within the active sunshine hours at ambient conditions and milled after removing the seed coat (DTS). Different processing treatments were adopted for each of the remaining portions. The treatments were: roasting (RTS), boiling (BTS) and autoclaving (ATS) to enhance removal of the seeds from the seed coat, followed by drying, dehulling and milling (Figure 1).
\end{abstract}

\section{Roasting}

After preliminary investigation, $500 \mathrm{~g}$ of tamarind seeds were roasted in an open pan placed on an electric stove at a temperature range of $100-120^{\circ} \mathrm{C}$ for $15 \mathrm{~min}$. The roasted seeds were de-hulled after breaking the cotyledons with the attrition mill and the seed coats removed by abrasion (rubbing inbetween palms) and winnowing. The cotyledons were sun-dried and milled into flour using attrition mill and sifted through a 1-mm mesh size sieve, packaged in air- tight plastic containers and stored under laboratory room temperature.

\section{Boiling}

In this method, $500 \mathrm{~g}$ of the seeds were cooked in boiling water for $30 \mathrm{~min}$. (Akajiaku et al., 2014). The seeds were sun-dried and milled into flour. The flour was sifted through a 1-mm mesh size sieve, packaged in an air tight container and stored under laboratory room temperature.

\section{Autoclaving}

Five hundred grammes $(500 \mathrm{~g})$ of the seeds were soaked in sufficient clean water for $1 \mathrm{~h}$, autoclaved for $15 \mathrm{~min}$. at $121^{\circ} \mathrm{C}$, cooled and the seed coat removed by abrasion and hand picking. De-hulled seeds were hot oven dried at $60^{\circ} \mathrm{C}$ for $8 \mathrm{~h}$. to a constant moisture content of $8.30 \%$ and milled into flour. The flour was sifted through a 1-mm mesh size sieve and packaged in an air-tight container.

\section{Production of flour from whole raw seeds}

Five hundred grammes $(500 \mathrm{~g})$ of the sun-dried seeds were sorted, milled, sieved and packaged in airtight container to obtain the first control sample.

\section{Production of flour from the raw seeds de-hulled} Five hundred grammes $(500 \mathrm{~g})$ of the sun-dried seeds were de-coated by breaking them using at attrition mill and then separated from the seed coat, milled, sieved and packaged in an airtight container to obtain a second control sample.

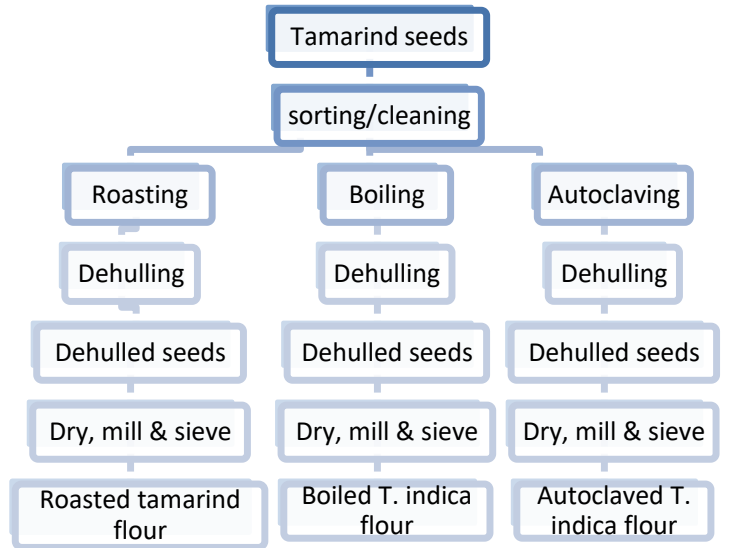

Figure 1: Production of tamarind seed flour Source: Akajiaku et al. (2014)

\section{Analytical Methods}

Determination of flour proximate composition The moisture, crude protein, crude fat, ash, crude fibre and carbohydrate by difference were carried out using AOAC (2010) method. All analysis was carried out in triplicates and values obtained reported in percentages.

Determination of water/oil absorption capacities Water absorption capacity was determined according to the method of Phillips et al. (1988) with slight modifications. One gramme (dry weight basis) of sample was dispersed in $10 \mathrm{ml}$ distilled water, vortexed intermittently for $10 \mathrm{~min}$. and centrifuged at $4500 \mathrm{rpm}$ for $20 \mathrm{~min}$. The aqueous supernatant obtained after centrifuging was decanted and the test tubes were inverted and allowed to drain for $5 \mathrm{~min}$. on a towel. By weighing the residue, water absorption capacity was calculated as percentage of gram of water absorbed per gram of sample.

Oil absorption capacity was determined by the method of Beuchat (1977). About $0.50 \mathrm{~g}$ of each powder sample was mixed with $5 \mathrm{ml}$ of oil for 30 seconds. The samples were then allowed to stand at room temperature $\left(30.0 \pm 2^{\circ} \mathrm{C}\right)$ for $30 \mathrm{~min}$. after which they were centrifuged at $5000 \mathrm{rpm}$ for 30 $\min$. The supernatant, mainly oil was decanted, and the test tubes inverted and allowed to drain for 15 min. on a towel. By weighing the residue, oil absorption capacity was calculated as grams of oil absorbed per gram of samples.

\section{Determination of emulsifying capacity and emulsion stability}

Emulsifying capacity was determined by the procedure of Beuchat et al. (1975), while emulsion stability was also evaluated using that of Pearce and Kinsella (1978). About $0.5 \mathrm{~g}$ of the sample was suspended in $3 \mathrm{ml}$ of distilled water contained in a graduated tube followed by the successive addition of $3 \mathrm{ml}$ of cottonseed oil. The mixture was vigorously mixed for $10 \mathrm{~min}$. using an agitator. The 
resulting emulsion was centrifuged at $2500 \mathrm{rpm}$ for $30 \mathrm{~min}$. The height of the emulsified layer divided by that of the whole slurry multiplied by 100 was taken as the emulsifying capacity of the sample.

For the emulsion stability, the homogenized mixture of powder, water and oil were heated at $80^{\circ} \mathrm{C}$ for $30 \mathrm{~min}$. before centrifugation. The emulsion stability was calculated as the height of the emulsifying layer divided by that of the heated slurry multiplied by 100 .

\section{Determination of bulk density}

The bulk density was determined by the method described by Onwuka (2018). A 10-ml capacity graduated measuring cylinder was weighed. The cylinder was gently filled with the sample followed by tapping the bottom until there was no further diminution of the sample level after filling to the 10-ml mark. The bulk density was calculated as:

$$
\mathrm{Bulk} \text { density }\left(\frac{g}{m l}\right)=\frac{\text { weight of sample }}{\text { volume of sample }}
$$

\section{Determination of swelling power}

The method described by Daramola and Osanyinlusi (2006) was used to determine the swelling power with slight modifications. The flour sample $(0.1 \mathrm{~g})$ was weighed into a test tube and 10 $\mathrm{ml}$ of distilled water was added. The mixture was heated in a water bath at a temperature of $50^{\circ} \mathrm{C}$ for $30 \mathrm{~min}$. with continuous shaking. Centrifugation was then carried out at $1500 \mathrm{rpm}$ for $20 \mathrm{~min}$. in order to facilitate the removal of the supernatant which was carefully decanted, and weight of the starch paste taken. The swelling power was calculated as follows:

$$
\text { Swelling power }=\frac{\text { Weight of starch paste }}{\text { weight of dry starch }}
$$

\section{Determination of mineral contents (magnesium,} potassium, sodium and phosphorus)

The mineral contents of the flours were determined using atomic absorption spectrophotometer (Perkin Elmer, model number: 2380, USA) as detailed in International Institute of Tropical Agriculture (IITA) manual for methods of mineral analysis with procedure similar to that described in Onwuka (2018). About $0.50 \mathrm{~g}$ sample was weighed into a clean ceramic crucible and the weight recorded to the nearest $0.001 \mathrm{~g}$. One empty crucible was included for a blank. The sample was placed in a cool muffle furnace and temperature set to $500{ }^{\circ} \mathrm{C}$ over a period of $2 \mathrm{~h}$. This remained at $500{ }^{\circ} \mathrm{C}$ for an additional $2 \mathrm{~h}$. The sample was allowed to cool inside desiccators in the analysis room. The ashed sample was then poured first into an already labeled $50 \mathrm{ml}$ centrifuge tube. The crucible was rinsed with $5 \mathrm{ml}$ of distilled water into the centrifuge tube. The crucible was rinsed again with $5 \mathrm{ml}$ of aqua regia up to 4 times (Preparation: In a 2-liter volumetric flask, 1.2 liter distilled water was added followed by careful addition of $400 \mathrm{ml}$ Conc. $\mathrm{HCl}$ and $133 \mathrm{ml}$ of $70 \%$ Nitric acid. The flask and its content were dilute to 2 liters.). The sample was vortexed for proper mixing. This was followed with centrifugation for $10 \mathrm{~min}$. at $3000 \mathrm{rpm}$. The supernatant was decanted into clean vials for macro and micronutrients determination using atomic absorption spectrophotometer.

\section{Determination of anti-nutrients Determination of tannin content}

Tannin content was determined using Folin-Denis spectrophotometric method described by Singh et al. (2012). One gramme of each sample was dispersed in $10 \mathrm{ml}$ of distilled water, shaken and allowed to stand for $30 \mathrm{~min}$. at $28^{\circ} \mathrm{C}$ before it was centrifuged to get the extract. About $2.5 \mathrm{ml}$ of the supernatant (extract) was dispersed into a $50 \mathrm{ml}$ volumetric flask. Similarly, $2.5 \mathrm{ml}$ of standard tannic acid solution was dispersed into a separate $50 \mathrm{ml}$ flask. One $\mathrm{ml}$ Folin-Denis reagent was measured into each flask, followed by $2.5 \mathrm{ml}$ of saturated $\mathrm{Na}_{2} \mathrm{CO}_{3}$ solution. The mixture was diluted to mark in the flask $(50 \mathrm{ml})$, and incubated for $90 \mathrm{~min}$. at $28^{\circ} \mathrm{C}$. The absorbance was measured at $250 \mathrm{~nm}$ in a spectrophotometer. Readings was taken with the reagent blank at zero. The tannin content was calculated as follows:

$$
\% \text { Tannin }=\frac{A n}{A s} \times C \times \frac{100}{W} \times \frac{V f}{V a}
$$

where $A n$ is absorbance of test sample, $A s$ is absorbance of standard solution, $C$ is concentration of standard solution, $W$ is weight of sample, $V f$ is total volume of extract, and $V a$ is volume of extract.

\section{Determination of hydrogen cyanide}

The alkaline picrate method described by Onwuka (2018) was used. Five grammes (5 g) of each of the different flour were dissolved in $50 \mathrm{ml}$ distilled water in a corked conical flask. The cyanide extraction was allowed to stay overnight and then filtered. About $4 \mathrm{ml}$ alkaline picrate was added to 1 $\mathrm{ml}$ of the filtrate and incubated in the water bath. After colour development, the absorbance was read at $490 \mathrm{~nm}$. The absorbance of the blank containing only one $\mathrm{ml}$ distilled water and $4 \mathrm{ml}$ alkaline picrate solution was read.

The cyanide content was extrapolated from a cyanide standard curve, prepared from different concentrations of $\mathrm{KCN}$ solution containing 5-50 $\mu \mathrm{g}$ cyanide in a $500 \mathrm{ml}$ conical flask.

\section{Determination of trypsin inhibitor}

Trypsin inhibitor activity was determined by spectrophotometric method described in Onwuka (2018). About $1 \mathrm{~g}$ of the test sample was weighed and dispersed in $50 \mathrm{ml}$ of $0.5 \mathrm{M} \mathrm{NaCl}$ solution to obtain sample extract. The mixture was stirred for 
30 min. at room temperature and centrifuged. The supernatants were filtered through watchman No. 41 filter paper and the filtrate utilized for the assay. Standard trypsin was prepared using BAPA $(\mathrm{N}-\alpha-$ Benzoyl-DL-Arginine-P-nitroanilide) reagent which was added to the filtrate/extract. Two millilitres $(2 \mathrm{ml})$ of the standard trypsin solution was added to $10 \mathrm{ml}$ of sample extract in a test tube. A blank of $10 \mathrm{ml}$ of substrate was also prepared but did not contain the extract. The contents of the test tubes stood for $10 \mathrm{~min}$. and measurement was carried out using Spectronic 401 spectrophotometer at $410 \mathrm{~nm}$, wavelength. Trypsin inhibitor activity expressed as number of try sin units inhibited per unit weight of sample was calculated as follows:

$$
\begin{gathered}
\frac{T I U}{m g}=\frac{\text { Absorbance of sanple } \times 0.01 F}{\text { Absorbance of standard }} \\
T I U / m g=\frac{b-a \times F}{0.01}
\end{gathered}
$$

where $b$ is absorbance of test sample solution, $a$ is absorbance of the blank and $F$ is experimental factor given by $F=\frac{1}{w} \times \frac{V f}{V a} \times D$; with $w$ as weight of sample, $V_{f}$ as total volume of the extract, $V_{a}$ as volume of the extract used in the assay, and $D$ as dilution factor.

\section{Determination of alkaloids}

This was determined using the method described in Onwuka (2018). Five grammes $(5.0 \mathrm{~g})$ of flour sample was weighed and dispersed into $50 \mathrm{ml}$ of $10 \%$ acetic acid solution in ethanol. The mixture was well shaken and stood for $4 \mathrm{~h}$ before filtering. The filtrate was evaporated one-quarter of its original volume and concentrated ammonia solution $\left(\mathrm{NH}_{4} \mathrm{OH}_{\mathrm{aq}}\right)$ was added drop wise to precipitate alkaloids. The precipitate was separated using weighed filter paper and washed with $1 \% \mathrm{NH}_{4} \mathrm{OH}_{\mathrm{aq}}$. The precipitate in the filter paper was dried in hot air oven at $60^{\circ} \mathrm{C}$ for $30 \mathrm{~min}$. and reweighed.

$$
\% \text { Alkaloids }=\frac{w 2-w 1 \times 100}{w}
$$

where $w 2$ is weight of filter paper + precipitate, $w 1$ is weight of filter paper, and $w$ is weight of sample.

\section{Determination of pasting properties}

Pasting properties of flour samples were determined using Rapid Visco-Analyser (RVA-Model RVA 3D) series 4 (New Scientific P.V.T Ltd, Australia, 1998) with the aid of the rmocline for windows version 1.1 software). Three grammes $(3.0 \mathrm{~g})$ of each of the flour sample were weighed into a dried empty canister and $25 \mathrm{ml}$ of distilled water was added to obtain flour dispersion after thorough mixing. The canister with dispersion was then fitted well into the RVA as indicated by the procedure and heated from $50-95{ }^{\circ} \mathrm{C}$ with a holding time of $2 \mathrm{~min}$. followed by cooling to $50{ }^{\circ} \mathrm{C}$ with $2 \mathrm{~min}$. holding time. Heating and cooling were at a constant rate of
11.25 ${ }^{\circ} \mathrm{C} / \mathrm{min}$ (Newport Scientific, 1998). Peak viscosity, peak time, trough viscosity, breakdown viscosity, setback viscosity, final viscosity and pasting temperature were read from the pasting profile using the rmocline for windows software connected to a computer (Newport Scientific, 1998).

\section{Experimental design and data analysis}

The experiment was carried out based on completely randomized design. Data collected from physicochemical (proximate, mineral composition, among others) and anti-nutrient determinations were subjected to one-way analysis of variance. Means were separated using least significant difference (Steel and Torrie, 1980) and significance was accepted at $p<0.05$.

\section{RESULTS AND DISCUSSION \\ Effect of Processing Methods on the Flour}

The different flours produced from the seeds are presented in (Plates 1 to 5). The flours had different colours due to the different processing methods. Flour from boiling and roasting had very fine particles as compared to others.
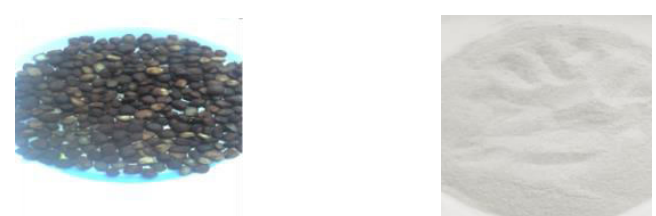

Plate 1: Autoclaved tamarind seeds and seed flour

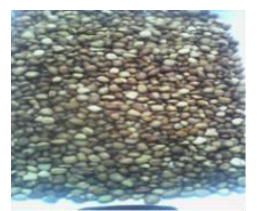

Plate 2: Boiled tamarind seeds and seed flour
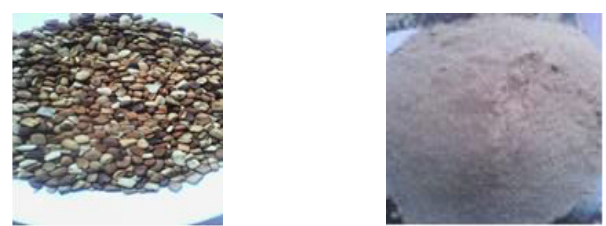

Plate 3: Roasted tamarind seeds and seed flour
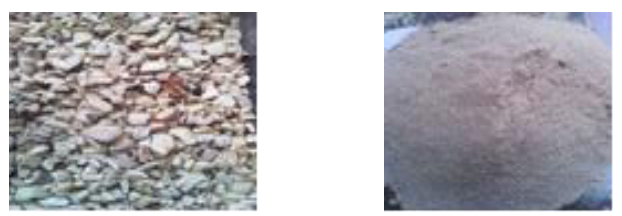

Plate 4: Dehulled raw tamarind seeds and seed flour
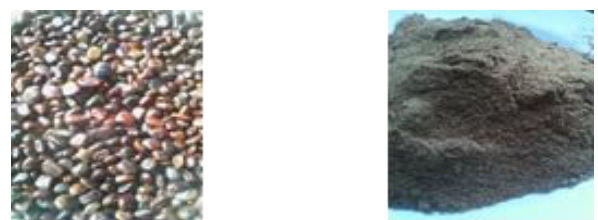

Plate 5: Undehulled raw tamarind seeds and seed flour 


\section{Effect of Processing Methods on Proximate Composition of Tamarind Seed Flours}

Proximate composition of autoclaved (ATS), boiled (BTS), roasted (RTS), dehulled raw seed (DTS) and undehulled raw seed flours (UTS) are shown in Table 1. Moisture contents of the samples ranged from 10.26-11.36\% with sample ATS having the least value $(10.26 \%)$. Significant $(p<0.05)$ differences existed among the samples and could be due to different processing methods. However, the values are within the range $(10-14 \%)$ required for the safe keeping of flours (SON, 2007). Protein content of the samples ranged from 19.64-24.23\%. Sample BTS has the least value (19.64\%) among others. The values were within the range of $20-37 \%$ reported by Glew et al. (1997) for indigenous plants of Burkina Faso. Proteins and starch contained in flours are water loving (hydrophilic) and hence, the ATS, RTS and BTS flours, could be used as components in baking flours especially for proper dough development (Onwurafor et al., 2017). The raw dehulled and undehulled flour samples were also high in protein contents but cannot be used in any food formulation without further processing for their flours might contain other toxins at high concentration in addition to very dark colour.

Fat content of the flour samples ranged from 2.26 to $4.13 \%$, with significant $(p<0.05)$ differences among them. The fat composition agrees with the nutritional and anti-nutritional properties of underexploited legumes species reported by Siddhuraju et al. (1995). Processing of the seeds based on boiling and autoclaving significantly $(p<0.05)$ resulted to reduction in fat contents of the ATS and BTS flours and could be due to type of heating methods applied. Roasting involved mainly dry heating. Crude fibre content of flour samples ranged from 3.25 to $4.55 \%$. Sample BTS had the least value $(3.25 \%)$. The values obtained in experimental study were lower than an earlier report of $6.0-7.0 \%$ on same tamarind species by Oluseyi and Temitayo (2015), and might be due to different processing methods. Fibre is important in human system when consumed through diets and could decrease bad cholesterol (LDL) levels, risk of coronary heart disease, colon and breast cancer (Plaami, 1997).

Ash contents of the samples ranged from 3.48 to $3.98 \%$ and there were no significant $(p>0.05)$ differences among the samples and indicated that the processing methods did not relatively affect the mineral composition of the ATS, BTS and RTS flours. Values were within the range of 3.20-4.60\% reported in Nigeria for under-utilized legume flours (Aremu et al., 2006) and 4.10-4.30\% recorded by Oluseyi and Temitayo (2015) on processing of tamarind seeds into flours using different methods. Total carbohydrate contents of the samples ranged from 52.89 to $59.86 \%$ and significant $(p<0.05)$ differences existed among them. Carbohydrate content values were found to be higher than those of earlier investigation on wild pulses such as Afzelia Africana (Madubuike et al., 1994) and those of Oluseyi and Temitayo (2015). The differences in quantities might be due to variations in cultivars and wide genetic diversity found in different geographical locations of the world as noted in Oluseyi and Temitayo (2015).

\section{Effect of Processing Methods on Functional Properties of Tamarind Seed Flours}

Functional properties of tamarind seed flours are shown in Table 2. Water absorption capacity (WAC) ranged from 89.66 to $97.46 \%$ with ATS having the lowest value $(89.66 \%)$ among the processed flours. There were significant $(p<0.05)$ differences among them. However, no significant $(p>0.05)$ differences existed between the values for boiled and roasted samples. Water absorption affects the quality of baked goods and depends partly on the damaged starch contained in the flour, the protein content and particle size (Kulkarni et al., 1991). Higher values for boiled and roasted flours WAC indicated that they could be included into aqueous food formulations in food processing that would involve preparation of dough such as baking. For instance, some reports (Aprianita et al., 2014; Ramashia et al., 2017) indicated that flour with high WAC encouraged initial softness in bread, while decreasing unnecessary firmness. It also enhanced smoothness and viscosity of the baked product. Emulsion capacity ranged from 34.35 to $46.12 \%$. There were no significant $(p>0.05)$ differences in the values for RTS and ATS flours and could show that both processing methods did not affect their emulsion capacities. The values for boiled and autoclaved flours also indicated their suitability for stable emulsions that cannot easily coalesce and flocculate (Subago, 2006). Hence, they could be used with wheat flour as composite in food formulations since values recorded in the study were higher than range (14.67-20.35\%) reported for wheat flour (Ukom et al., 2017).

Table 1: Proximate composition of the tamarind seed flours

\begin{tabular}{lcccccc}
\hline $\begin{array}{l}\text { Flour } \\
\text { samples }\end{array}$ & $\begin{array}{c}\text { Moisture } \\
(\%)\end{array}$ & $\begin{array}{c}\text { Crude protein } \\
(\%)\end{array}$ & $\begin{array}{c}\text { Crude fat } \\
(\%)\end{array}$ & $\begin{array}{c}\text { Crude fibre } \\
(\%)\end{array}$ & $\begin{array}{c}\text { Ash } \\
(\%)\end{array}$ & $\begin{array}{c}\text { Carbohydrate } \\
(\%)\end{array}$ \\
\hline ATS & $10.26^{\mathrm{a}} \pm 0.01$ & $20.24^{\mathrm{b}} \pm 0.01$ & $2.26^{\mathrm{a}} \pm 0.01$ & $3.97^{\mathrm{b}} \pm 0.01$ & $3.98^{\mathrm{b}} \pm 0.01$ & $59.29^{\mathrm{d}} \pm 0.00$ \\
BTS & $11.36^{\mathrm{a}} \pm 0.01$ & $19.64^{\mathrm{a}} \pm 0.01$ & $2.35^{\mathrm{a}^{\mathrm{a}} \pm 0.01}$ & $3.25^{\mathrm{b}} \pm 0.01$ & $3.56^{\mathrm{b}} \pm 0.01$ & $59.84^{ \pm} \pm 0.02$ \\
RTS & $10.88^{\mathrm{a}} \pm 0.01$ & $22.26^{\mathrm{a}} \pm 0.01$ & $3.66^{ \pm} \pm 0.01$ & $4.55^{\mathrm{a}} \pm 0.01$ & $3.73^{\mathrm{b}} \pm 0.01$ & $54.92^{ \pm} \pm 0.01$ \\
DTS & $10.66^{\mathrm{b}} \pm 0.01$ & $24.23^{\mathrm{a}} \pm 0.01$ & $4.13^{\mathrm{a}^{ \pm} \pm 0.01}$ & $4.47^{\mathrm{a}} \pm 0.01$ & $3.64^{\mathrm{b}} \pm 0.01$ & $52.87^{\mathrm{a}} \pm 0.014$ \\
UTS & $11.15^{\mathrm{d}} \pm 0.01$ & $23.37^{\mathrm{d}} \pm 0.01$ & $3.98^{\mathrm{d}^{ \pm} \pm 0.01}$ & $4.16^{\mathrm{e}} \pm 0.01$ & $3.48^{\mathrm{b}} \pm 0.01$ & $53.86^{\mathrm{b}} \pm 0.01$ \\
\hline
\end{tabular}


The values for bulk density values of the samples ranged from 0.45 to $0.48 \mathrm{~g} / \mathrm{ml}$. There were no significant $(p>0.05)$ differences in values among the flours but the values were slightly lower than those of Bambara groundnut flour $(0.60-0.75 \mathrm{~g} / \mathrm{ml})$ reported by Onimawo et al. (1998). Bulk density is very important in determining the packaging materials for flours, material handling and application in wet processing in the food industries (Karuna et al., 1996). Low values obtained for the processed flours in bulk density might imply that the powdered processed samples would have application in complementary food formulations for infants. Swelling power ranged from 10.24 to $11.13 \%$. There were no significant $(p>0.05)$ differences in the swelling power of the different samples. The swelling power could be dependent on association binding within the starch granules and strength and character of the micelle network in relation to amylose content of the flour (Adebowale et al., 2005). Therefore, swelling power has direct relationship with WAC.

Effect of Processing Methods on Mineral Composition of Tamarind Seed Flours

Selected mineral composition of tamarind seed flours is presented in Figure 1. Sodium content ranged from $73.35-122.26 \mathrm{mg} / 100 \mathrm{~g}$. The ATS and RTS flours had significantly $(p<0.05)$ higher values for sodium content than flour from boiling method. This could be due to leaching of the mineral into water during processing, while complex reaction during roasting of the seeds might reduce amount of sodium in the roasted flour. However, both ATS and RTS flours were fair sources of sodium. The mineral is required for regulation of acid-base balance and osmotic pressure in human body system (Maher and Escort-Stump, 2004). As a macro-mineral, adults up to 50 years require $2.4 \mathrm{~g} /$ day, while 50-70 years need $2.2 \mathrm{~g} /$ day (Maher and Escort-Stump, 2004).

The sodium content for the processed flours was relatively higher than an earlier report of same species of tamarind seeds studied by Ishola et al. (1990). Magnesium content ranged from 2.95 to $3.56 \mathrm{mg} / 100 \mathrm{~g}$. Sample ATS had the highest magnesium content among processed flours. However, results indicated that the seeds were relatively low sources of magnesium as compared to daily nutrient intake by adults' females and males that varied between 220 and $260 \mathrm{mg} /$ day (FAO, 2004). Magnesium is important in the formation of body's main energy compound called adenosine triphosphate (ATP), nerve impulse transmissions and muscle contractions. Potassium was the highest mineral recorded for all the flours and significant $(p<0.05)$ differences existed among the samples. Sample RTS had the highest potassium content $(478.86 \mathrm{mg} / 100 \mathrm{~g})$ followed by ATS $(460.26 \mathrm{mg} / 100 \mathrm{~g})$. An earlier report on all the minerals by Ajayi et al. (2006) indicated that $\mathrm{K}$ had the highest concentration in under-utilized legumes, and this agrees with the results in the present report. This is nutritionally significant $(p<0.05)$ since potassium plays major role in neuro-muscular function, acid-base fluid and electrolyte balance, osmotic pressure, enzyme reactions, among others (Ajayi et al., 2006; FAO, 2004). The processed $T$. indica seed flours of experimental study were found to contain more than adequate level of potassium compared to recommended dietary allowance (RDA) of Anonymous (2019). Adeola and Aworh (2012) pointed out that sodium to potassium ratio (Na: K) was important for proper balancing of the heart pressure in human system and for this to be achieved $\mathrm{NaK}^{-1}$ must be less than one. Hence, values calculated for the ratios of the minerals in the processed flours showed that ATS had 0.26, while values for BTS and RTS were 0.17 and 0.27 , respectively. Phosphorus content of the sample ranged from 120.26 to $153.36 \mathrm{mg} / 100 \mathrm{~g}$. The contents were relatively higher for all the processed flours but BTS had lowest value among the flours and could be due to the processing method. Phosphorus mineral participates in buffering the human body system, is part of DNA and RNA and helps in energy metabolism (Paul et al., 2018).

Table 2: Functional properties of tamarind flour samples

\begin{tabular}{lcccc}
\hline $\begin{array}{l}\text { Sample } \\
\text { flours }\end{array}$ & $\begin{array}{c}\text { Water } \\
\text { absorption } \\
\text { capacity }(\%)\end{array}$ & $\begin{array}{c}\text { Emulsion } \\
\text { capacity } \\
(\%)\end{array}$ & $\begin{array}{c}\text { Bulk } \\
\text { density } \\
(\mathrm{g} / \mathrm{ml})\end{array}$ & $\begin{array}{c}\text { Swelling } \\
\text { Power } \\
(\%)\end{array}$ \\
\hline ATS & $89.66^{\mathrm{a}} \pm 0.01$ & $45.37^{\mathrm{d}} \pm 0.01$ & $0.48^{\mathrm{a}} \pm 0.00$ & $10.67^{\mathrm{a}} \pm 0.01$ \\
BTS & $96.35^{\mathrm{d}} \pm 0.02$ & $38.38^{\mathrm{b}} \pm 0.01$ & $0.45^{\mathrm{a}} \pm 0.00$ & $11.13^{\mathrm{b}} \pm 0.01$ \\
RTS & $95.16^{\mathrm{d}} \pm 0.01$ & $46.12^{\mathrm{d}} \pm 0.01$ & $0.46^{\mathrm{a}} \pm 0.00$ & $10.36^{\mathrm{ac}} \pm 0.01$ \\
DTS & $97.46^{\mathrm{e}} \pm 0.01$ & $34.35^{\mathrm{a}} \pm 0.01$ & $0.46^{\mathrm{a}} \pm 0.00$ & $10.24^{\mathrm{a}} \pm 0.02$ \\
UTS & $91.47^{\mathrm{b}} \pm 0.01$ & $41.16^{\mathrm{c}} \pm 0.01$ & $0.45^{\mathrm{a}} \pm 0.00$ & $10.45^{\mathrm{a}} \pm 0.01$ \\
\hline
\end{tabular}

Values are means for three determinations \pm standard deviation.

Mean values with same superscript in the same column are not significantly $(p>0.05)$ different.

ATS - Autoclaved tamarind seed flour; BTS - Boiled tamarind seed flour; RTS - Roasted tamarind seed flour; DTS - Dehulled raw tamarind seed flour; UTS - Undehulled raw tamarind seed flour

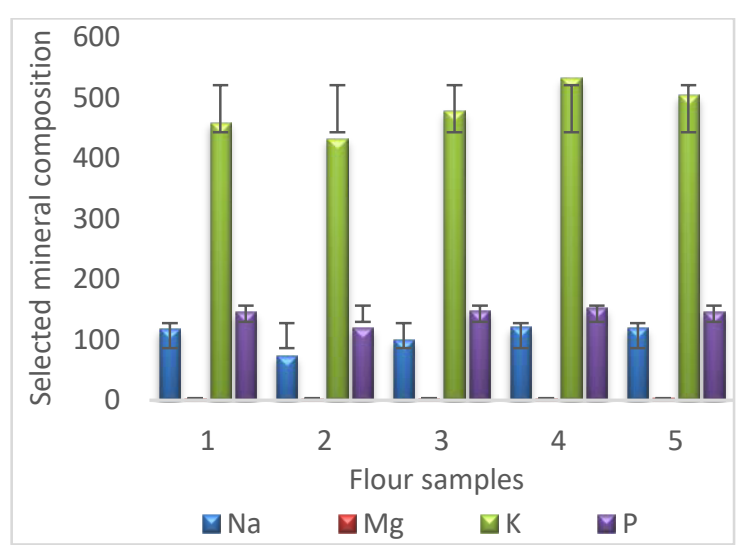

Figure 1: Mineral composition of the processed tamarind seed flours

1 - Autoclaved tamarind seeds; 2 - Boiled tamarind seeds;

3 - Roasted tamarind seeds; 4 - Dehulled raw tamarind seeds;

5 - Undehulled raw tamarind seeds 


\section{Effect of Processing Methods on Anti-Nutrient Composition of Tamarind Seed Flours}

Anti-nutrient composition of tamarind seed flours is shown in Table 3. Tannin content ranged from 2.63 to $4.21 \mathrm{mg} / 100 \mathrm{~g}$. Samples BTS and ATS had lower tannin contents than sample RTS. The lower content in BTS and ATS could be attributed to solubility of some tannin in water during soaking and heating (Uzogara et al., 1990) of the seeds. There are water soluble and insoluble tannins and these organic compounds commonly form insoluble complexes with protein making them non-bioavailable. However, values of the experimental study were all within acceptable levels (<76-90 g kg/dry matter); lower the value, the better for the processed flour utilization in food product development. Research findings of Aletor and Adeogun (1995) on nutrient and antinutrient composition of some tropical leafy vegetables highlighted that tannin contents as high as 76-90 $\mathrm{g}$ $\mathrm{kg} / \mathrm{dry}$ matter might be harmful when consumed.

Hydrogen cyanide contents of the samples ranged from $0.24-0.86 \mathrm{mg} / 100 \mathrm{~g}$ and values were relatively lower for all the flours but exceptionally lowest for the roasted flour. This can be attributed to heat application which has been reported to reduce cyanogen's content (Sathe and Salunkhe, 1984). High concentrations of hydrogen cyanide can be very poisonous to human health if consumed. Trypsin inhibitor activity of tamarind seed flours range from 7.67-20.05 TIU/mg. Boiling method significantly $(p<0.05)$ reduced trypsin inhibitor of the tamarind seeds from 20.05 of undehulled seeds to $7.67 \mathrm{TIU} / \mathrm{mg}$ in the boiled seed flour. Trypsin is an enzyme involved in the breakdown of many different proteins during digestion in humans, monogastrics and young ruminants.

Trypsin inhibitors are proteins that reduce biological activity of trypsin by controlling the activation and catalytic reactions of proteins and compete with proteins to bind to trypsin and therefore render them unavailable to bind with proteins for the digestion process; example, protease inhibitors. Reduction in trypsin content might be attributed to effect of heat denaturation during boiling. Kanwar et al. (1991) recorded that cooking removes trypsin inhibitor activity by more than $98 \%$. Alkaloid contents of the samples ranged from $23.34-30.05 \mathrm{mg} / 100 \mathrm{~g}$ and were higher than other anti-nutrient contents recorded.

Table 3: Anti-nutrient composition of tamarind seed flours

\begin{tabular}{cllll}
\hline $\begin{array}{l}\text { Flour } \\
\text { samples }\end{array}$ & $\begin{array}{l}\text { Tannin } \\
(\mathrm{mg} / 100 \mathrm{~g})\end{array}$ & $\begin{array}{l}\text { HCN } \\
(\mathrm{mg} / 100 \mathrm{~g})\end{array}$ & $\begin{array}{l}\text { Trypsin } \\
(\mathrm{TIU} / \mathrm{mg})\end{array}$ & $\begin{array}{l}\text { Alkaloid } \\
(\mathrm{mg} / 100 \mathrm{~g})\end{array}$ \\
\hline ATS & $2.68^{\mathrm{b}} \pm 0.01$ & $0.64^{\mathrm{b}} \pm 0.00$ & $13.59^{\mathrm{b}} \pm 0.01$ & $24.49^{\mathrm{b}} \pm 0.01$ \\
BTS & $2.63^{\mathrm{b}} \pm 0.01$ & $0.24^{\mathrm{a}} \pm 0.01$ & $7.67^{\mathrm{a}} \pm 0.01$ & $28.45^{\mathrm{d}} \pm 0.01$ \\
RTS & $3.98 \mathrm{~d}^{\mathrm{d}} \pm 0.01$ & $0.67^{\mathrm{b}} \pm 0.01$ & $17.57^{\mathrm{c}} \pm 0.02$ & $23.34^{\mathrm{a}} \pm 0.01$ \\
DTS & $3.81^{\mathrm{d}} \pm 0.02$ & $0.86^{\mathrm{b}} \pm 0.01$ & $18.66^{\mathrm{d}} \pm 0.01$ & $26.66^{\mathrm{c}} \pm 0.01$ \\
UTS & $4.21^{\mathrm{e}} \pm 0.02$ & $0.74^{\mathrm{b}} \pm 0.01$ & $20.05^{\mathrm{e}} \pm 0.01$ & $30.05^{\mathrm{e}} \pm 0.01$ \\
\hline
\end{tabular}

Values are means for three replications, \pm Standard deviations. Mean values with same superscript in the same column are not significantly $(p>0.05)$ different. ATS- Autoclaved tamarind seeds; BTS- Boiled tamarind seeds; RTS- Roasted tamarind seeds; DTS- Dehulled raw tamarind seeds; UTS-Undehulled raw tamarind seeds
Alkaloids have dual functions. At high concentration most of them are toxic but have pharmacological effect at low concentrations. The RTS flour had lowest amount of alkaloids among others. Most alkaloids as organic nitrogen bases are bitter in taste. Tamarind seed alkaloids such as cochins and vinca are capable of inhibitory mitotic cell division; phagocytosis and can encourage lympho-toxic activities that are dangerous to health at low concentration (Higuchi and Hassan, 1973).

\section{Effect of Processing Methods on Pasting Properties of Tamarind Seed Flours}

Pasting properties of flour dispersions are presented in Figure 2. They are properties used to predict flour behaviours during and after cooking. Pasting temperatures (PTs) of all samples ranged from 82.38 to $84.55{ }^{\circ} \mathrm{C}$. There were no significant $(p>0.05)$ differences in the values for BTS, RTS and UTS flours. The BTS and RTS had also lower pasting temperatures than ATS. The PT is the temperature at which viscosity of flour dispersion first increase by at least $2 \mathrm{RVU}$ over a period of $20 \mathrm{sec}$. and indicates the temperature required to cook the flour starch beyond its gelatinization point (Adebowale et al., 2008). Gelatinization is an irreversible process that occurs when starch/starch-based foods are heated in water beyond a critical temperature, starch molecules' intermolecular bonds break down allowing the hydrogen bonding sites to engage more water and become hydrated. The irreversible process gives room for dissolution of starch granules and the chains separate into amorphous format that temperature based on the starch type. High PT values indicate the ability of the flour starch dispersion to resist swelling and rupturing that might be due to size of the granules and effect of the processing methods. The PT of the $T$. indica seed flours were generally lower than boiling temperature of water; hence the flours could form paste before boiling point of water was attained in $<7$ min. as indicated by the peak time. At commercial level, it is a remarkable way of saving cost.

Peak viscosity (PV) of the flour samples ranged from 49.35 to 66.77 RVU. The RTS flour had the highest value (66.77 RVU) among processed flours. Significant $(p<0.05)$ differences observed in processed samples are indicative of nature and composition of their starches. The PV is the maximum viscosity developed when portion of the test sample is heated. The viscosity has been reported to be closely associated with the degree of starch damage during stirring, amylose content and relative crystalline; and high damage enhances viscosity of paste (Sanni et al., 2001). This implied that the roasted flour dispersion would have high gel strength and gel forming potential during cooking than other processed flours and could be used in food preparations that would require high thickening power at high temperatures in food industries (Kim et al., 1995). However, all processed flour samples could be used for similar applications as their PV values ranged from 50.43-66.77 RVU. 


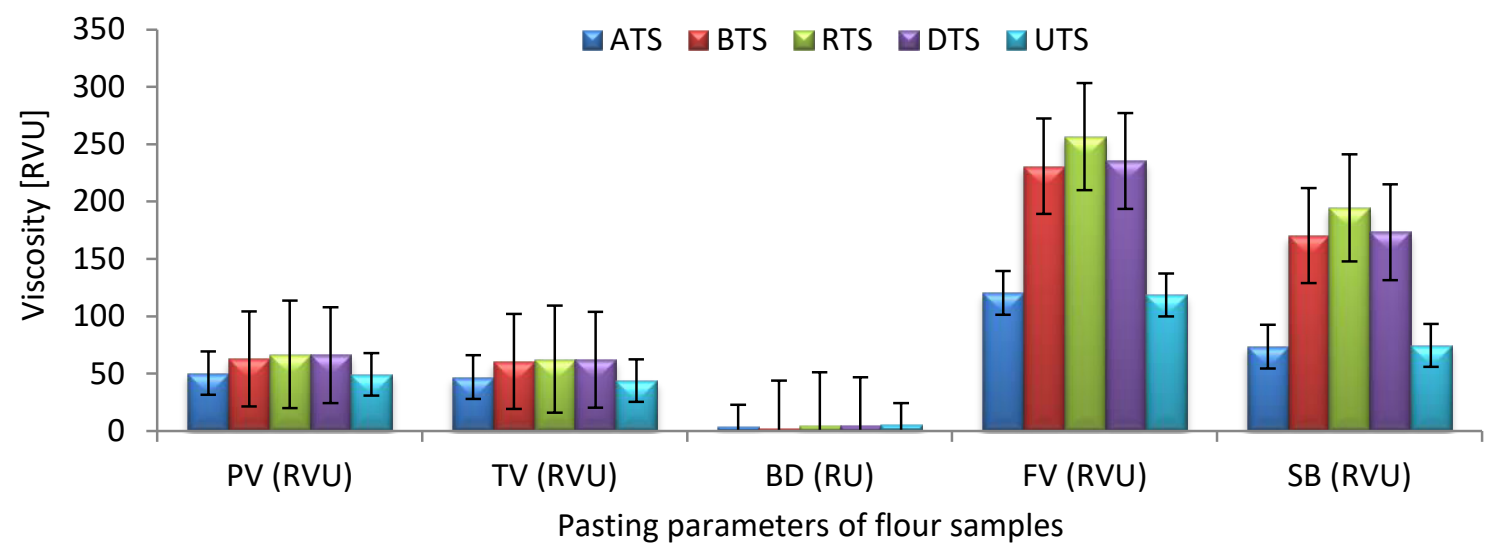

Figure 2: Flour sample dispersions and their viscosities during cooking

ATS - Autoclaved tamarind seeds; BTS - Boiled tamarind seeds; RTS - Roasted tamarind seeds; DTS - Dehulled raw tamarind seeds; UTS - Undehulledraw tamarind seeds; PV - peak viscosity, TV - trough viscosity, BD - breakdown viscosity,

FV - Final viscosity, SB - setback viscosity

Trough (holding strength) viscosity (TV) ranged from 43.93-62.52RVU. Sample ATS had lowest value of 46.92 RVU among processed flours. The TV is the ability of starch granules to remain undisrupted when the flour paste is subjected to a hold period of constant high temperature $\left(95^{\circ} \mathrm{C}\right.$ for 2.5 min.) and mechanical shear stress (Bakare, 2008). The holding strength was highest for RTS and DTS flour dispersions. Breakdown (BD) viscosity ranged from 2.27 to 5.52 RVU for all samples. Roasted sample had higher BD viscosity value (4.35 RVU) than other processed samples. The BD is a measure of tendency of the swollen starch granules to rupture when held at high temperatures and continuous stirring and an indicative of paste stability (Olkku and Rha, 1978; Akanbi et al., 2009). Adebowale et al. (2005) reported that higher values of BD viscosity for a cooked paste indicated lower ability of the flour sample to withstand heating and shear stress during cooking. Hence, flour sample from boiled $T$. indica seeds and ATS might withstand heating and shear stress compared to RTS that had highest BD value (4.35 RVU) among the processed samples.

Final viscosity $(\mathrm{FV})$ of the processed cooked flour dispersions ranged from 120.35 to 256.80 RVU. It is an indicator of potentials of flour dispersions to form viscous pastes on cooling. Roasted sample had higher value (256.80 RVU) than other processed samples. This viscosity recorded at the end of the test is related to cooked starch paste stability and highlighted assemblage/association of amylose molecules that could lead to faster retro-gradation (Miles et al., 1985; Lii et al., 1996). Shimelis et al. (2006) showed that less stability of starch paste or gel after cooling was commonly accompanied with high BD viscosity value.

Setback (SB) viscosity of processed flours varied between 73.52 and 194.44 RVU. It is the difference between final and trough viscosities and shows the tendency of starch to associate and retrograde. Peroni et al. (2006) suggested that flour with low SB might have low values of amylase with high molecular weight, while Ikegwu et al. (2010) observed that lower retro-gradation of starch paste was accompanied with high setback value. Hence, high value of RTS flour (194.44 RVU) was an indicative of less tendency to retrograde compared to ATS and BTS samples (73.52 and 170.35 RVU, respectively). However, all the processed flours could be useful in confectionary industries (Ajatta et al., 2016). Peak time ranged from 5.58 to $6.75 \mathrm{~min}$. for the RTS, BTS and ATS flours and was the period at which peak viscosity occurred. It is also an indicator to the ease of cooking the product. There was no significant $(p<0.05)$ difference in BTS and RTS values (5.99 and 5.88 min., respectively).

\section{CONCLUSION}

The study indicated that $T$. indica seed flours have good nutritional profile with high amounts of ash, protein, sodium, potassium and phosphorus. Hence, utilization of tamarind seeds as a protein ingredient in food would help to reduce over dependence on conventional protein supplements from soybean among common legumes. There were no significant $(p>0.05)$ differences in the values obtained for bulk density of all flours. All the processed flours formed pastes in hot water below boiling point of water and this could be a remarkable way of saving cost at commercial production. Boiling method was relatively more effective in reducing various antinutritional components of $T$. indica seeds but with little effect on the nutritional quality than others. The RTS cooked paste could withstand retrogradation and formed gel with higher strength than others. However, it had the lowest ability to withstand heating and shear stress during cooking.

\section{ACKNOWLEDGEMENTS}

The authors wish to acknowledge the help rendered during period of study by Department of Food Science and Technology and Biomass building laboratories, National Centre for Energy Research and Development, University of Nigeria, Nsukka, where various analyses were carried out. The same appreciation is extended to International Institute of Tropical Agriculture (IITA), Ibadan, Nigeria, where pasting properties, proximate and micronutrients composition were determined. 


\section{REFERENCES}

Adebowale A.A., Sanni L.O. and Awonorin S.O. (2005). Effect of texture modifiers on the physicochemical and sensory properties of dried fufu. Food Science \& Technology International, 11 (5), 73-382

Adebowale A.A., Sanni L.O. and Onitilo M.O. (2008). Chemical composition and pasting properties of tapioca grits from different cassava varieties and roasting methods. African Journal of Food Science, 2, 077-082

Adeola A.A. and Aworh O.C. (2012). A comparative evaluation of the chemical properties of wild tamarind (Tamarindus indica L.) fruits in Nigeria. Food, 6 (1), 49-57

Ajayi I.A., Oderinde R.A., Kajogbola D.O. and Uponi J.I. (2006). Oil content and fatty acid composition of some underutilized legumes from Nigeria. Food Chemistry, 99, $115-120$

Ajjata M.A., Akinola S.A. and Osundahunsi O.F. (2016). Proximate, functional and pasting properties of composite flours made from wheat, breadfruit and cassava starch. Applied Tropical Agriculture, 21 (3), 158-165

Akajiaku L.O., Nwosu J.N., Onuegbu N.C., Njoku N.E. and Egbeneke C.O. (2014). Proximate, minerals and anti-nutrient composition of processed tamarind seed nut. Current Res. Nutrition \& Food Sci., 2 (3), 136-145

Akanbi C.T., Nazamid S. and Adebowale A.A. (2009). Functional and pasting properties of a tropical breadfruit (Artocarpus altilis) starch from Ile Ife, Osun State, Nigeria. Int. Food Research Journal, 16, 151-157

Aletor V.A. and Adeogun O.A. (1995). Nutrient and antinutrient components of some tropical leafy vegetables. Food Chemistry, 53, 375-379

Anonymous (2019). Dietary guidelines for Americans, 2005, USDA. http://health.gov/dietaryguideline/dcga2005/ document $/ \mathrm{html} / \mathrm{chapter}$.htm. Accessed on 01-08-2019

AOAC (2010). Official Method of Analysis. Association of Official Analytical Chemists International, $18^{\text {th }}$ edition, Washington. D.C., USA

Aprianita A., Vasiljesic T., Banicova A. and Kasapis S. (2014). Physicochemical properties of flours and starches from traditional Indonesian tubers and roots. Journal of Food Science \& Technology, 51, 3669-3679

Aremu M.O., Olaofe O. and Akintayo T.E. (2006). A Comparative study on the chemical and amino acid composition of some Nigerian under-utilized legume flours. Pakistan Journal of Nutrition, 5 (1), 34-38

Bakare H.A. (2008). Evaluation of Rheological Properties and Baking Performance of Wheat Composite Flour Produced From Lye-Peeled Breadfruit (Artocarpus communis) and Cassava. Ph.D. Thesis, University of Ibadan, Nigeria, pp. 170

Beuchat L.R. (1977). Functional and electrophoretic characteristics of succinylated peanut flour proteins. Journal of Agricultural Food Chemistry, 25, 258-26

Beuchat L.R., Cherry J.B. and Quinn M.R. (1975). Physicochemical properties of peanut powder as affected by proteolysis. Journal of Agricultural Food Chemistry, 23, 616-620

Daramola B. and Osanyinlusi S.A. (2006). Production, characterization and applications of banana (Musa spp.) flour in whole maize. African Journal of Biotechnology, 5 (10), 992-995

El-Siddig K., Gunasen H.P.M., Prasa B.A., Pushpakumara D.K.N., Ramana K.V.R., Vijayanand P. and Williams J.T. (2006). Tamarind (Tamarindus indica L.) fruits for the future1. Southampton Centre for Underutilized Crops, Southampton, UK, 188
FAO (2004). Handbook on Human Nutrition Requirements: FAO Food and Nutrition Vitamin and Mineral Requirements: Second edition. www.fao.org Accessed on 07-12-2019

Glew R.H., VanderJagt D.J., Lockett C., Gravette L.E., Smith G.C., Pastuszyn A. and Millson M. (1997). Amino acid, fatty acid and mineral composition of 24 indigenous plants of BurkinaFaso. Journal of Food Composition and Analysis, 10, 205-217

Higuchi T. and Hassan B. (1973). Pharmaceutical Analysis. Litton educational Publication Incorporated, New York, pp. 100-116

Ikegwu O.J., Okechukwu P.E and Ekumenkana E.O. (2010). Physicochemical and pasting characteristics of flour and starch from Achi (Brachystegia eurycoma) seed. Journal of Food Technology, 8 (2), 58-66

Ishola M.M., Agabaji E.B. and Agbaji A.S. (1990). A chemical study of Tamarindus indica (Tsamiya)fruits grown in Nigeria. Journal of Science of Food and Agriculture, 51, 141-143

Kanwar J.R., Sharma P.B. and Kanwar S.S. (1991) Biochemical and nutritional characteristics of nonconventional protein sources. Journal of the Food and Agriculture, 55, 141-151

Karuna D., Noel G. and Dilip K. (1996). Food and nutrition bulletin, Vol. 17 No. 2, United Nation University

Kim Y.S., Wiesnborg D.P., Orr. P.H. and Grant L.A. (1995). Screening potato starch for novel properties using different scanning calorimeter. Journal of Food Science, 60, 1060-1065

Kulkarni K.D., Kulkarni D.N. and Ingle U.M. (1991). Sorghum malt-based weaning formulations preparation, functional properties and nutritive value. Food and Nutrition Bulletin, 13 (4), 322-327

Lii C.Y., Tsai M. and Tseng K.H. (1996). Effect of amylose content on rheological properties of rice starch. Cereal Chemistry, 73, 415-420

Madubuike F.N., Ojimelukwe P.C. and Ajah P.O. (1994). Proximate composition, energy content and physicochemical properties of Afzelia Africana and Brachystegiaeurycoma seeds. Plant Foods for Human Nutrition, 46, 339-344

Maher L.K. and Escott-Stump S. (2004). Krause's Food Nutrition and Dietary Therapy $\left(11^{\text {th }}\right.$ ed.). Elsevier, USA

Maziya-Dixon B., Dixon A.G.O. and Adebowale A.A. (2004). Targeting different end uses of cassava: genotypic variations for cyanogenic potentials and pasting. A paper presented on ISTRC-AB Symposium, 31 Oct-5 Nov., 2004, White sands Hotel Mombasa, Kenya

Miles M.J., Moris V.J., Orford P.D. and Ring S.G. (1985). The roles of amylose and amylopectin in the gelation and retrogradation of starch. Carbohydrate Research, 135 (2), 271-281

Newport Scientific (1998). Application manual for rapid visco-analyzer using thermocline for windows, Newport Scientific Pty Ltd, Australia, pp. 2-26

Olkku T. and Rha C. (1978). Gelatinisation of starch and wheat flour starch - a review. Food Chemistry, 3, 293-31

Onwurafor E.U., Umego E.C., Uzodinma E.O. and Samuel E.D. (2017). Chemical, functional, pasting and sensory properties of sorghum-maize-mungbean malt complementary food. Pakistan Journal of Nutrition, 16, 826-834

Oluseyi E.O. and Temitayo O.U. (2015). Chemical and functional properties of fermented, roasted and germinated tamarind (Tamarindus indica) seed flours. Journal of Nutrition and Food Science, 45 (1), 97-111 
Onimawo I.A., Momoh A.A. and Usman A. (1998). Proximate composition and functional properties of flour cultivars of Bambara groundnut (Voandzeia subterranean). Plant Foods for Human Nutrition, 53, 153-158

Onwuka G. I., (2018). Food Analysis and Instrumentation (Theory and practice). Second edition Naphthali Prints, Lagos, Nigeria, pp. 343, 353-359, 373

Paul S.H., Usman A.A., Gana I.N., Manase A., Adeniyi O.D. and Olutoye M.A. (2018). Comparative study of mineral and nutritional composition of a multifunctional flora composite formulated from seven medicinal plants and their applications to human health. Engineering Technology Journal, 1 (5), 001-0014

Peroni F.H.G., Roche T.S. and Franco C.M.L. (2006). Some structural and physicochemical characteristics of tuber and root starches. Food Science and Technology International, 12, 505-510

Pearce K.N. and Kinsella J.E. (1978). Emulsifying properties of proteins: evaluation of a turbidimetric technique. Agricultural Food Chemistry, 26 (3), 716-723

Phillips R.D., Chinnan M.S, Branch A.L., Miller J. and Mcwatters K.H. (1988).Effects of pre-treatment on functional and nutritional properties of cowpea meal. Journal of Food Science, 53, 805-809

Plaami S.P. (1997). Content of dietary fiber in foods and its physiological effects. Food Review International, 13 (1), 29-76

Ramashia S.E., Gwata E.T., Medows-Taylor S., Anyasi T.A. and Jideani A.I.O. (2017). Some physical and functional properties of finger millet (Eleusine coranana) obtained in Sub-Saharan Africa. Food Research International, 104, 110-118

Sathe S. K., Desphande S.S. and Salunkhe D. K. (1982). Functional properties of lupin seed (Lupinus mutabilis) protein and protein concentrates. Journal of Food Science, 47, 491-497

Sanni L.O., Ikuomola D.P. and Sanni S.A. (2001). Effect of length of fermentation and varieties on the quality of sweet potato gari. Proc. $8^{\text {th }}$ Triennial Symposium of the International Society for Tropical Root Crops Africa Branch (ISTRC-AB), Ed. M.O. Akoroda, IITA, Ibadan., Nigeria, 12-16 ${ }^{\text {th }}$ Nov., 2001, 208-211
Sanni L.O., Christiana A.B and Silifat A.S. (2004). Production of instant cassava noodles. Journal of Food Technology, 2, 83-89

Siddhuraju P., Vijayakumari K. and Janardhanan K. (1995). Nutritional and anti-nutritional properties of the under-exploited legumes (Cassia laevigata W. and Tamarindus indica L.). Journal of Food Composition and Analysis, 8, 351-362

Shimelis E., Meaza M. and Rakshit S. (2006). Physicochemical properties, pasting behaviour and functional characteristics of flour and starches from improved bean (Phaseolus vulgaris L.) varieties grown in East Africa. Ejournal of Agricultural Engineering International, 8, 1-18

Singh D., Wangchu L. and Moond S.K. (2007). Processed products of tamarind. Nigerian Product Radiance, 6 (4), 315-321

Steel R.G.D. and Torrie J.H. (1980). Principles and Procedures of Statistics ( $2^{\text {nd }}$ ed.) McGraw-Hill, New York

SON (2007). Nigerian industrial standards for pastes. Standard Organization of Nigeria. ICS (International Classifications Standard) 664, 68, pp. 1-8

Subago A. (2006). Characteristics of hyacinth bean (Labtab purpireus L.) sweet seeds from Indonesia and their proteins. Food Chemistry, 95 (1), 65-70

Shittu T.A., Lasekan O.O., Sanni L.O. and Oledosu M.O. (2001). The effect of drying methods on the functional and sensory characteristics of purpura fermented cassava product. ASSET, 1 (2), 9-16

Ukom A.N., Richard C.P. and Abasiekong S.K. (2017). Effect of processing on the proximate, functional and anti-nutritional properties of cocoyam (Xanthosoma mafa S.) flour. Nigerian Food Journal, 35 (2), 9-17

Uzogara S.G., Agu L.N. and Uzogara E.O. (1990). A review of traditional fermented foods, condiments and beverages in Nigeria: their benefits and possible problems. Ecology of Food Nutrition, 24 (4), 267-288 